\title{
DIVERSIFIKASI PRODUK TENUN IKAT NUSA TENGGARA TIMUR DENGAN PADUAN TEKNIK TENUN DAN TEKNIK BATIK
}

\section{Diversification of the East Nusa Tenggara Tie Weaving Product Produced with the Combination of Weaving and Batik Techniques}

\author{
Irfa'ina Rohana Salma, Dana Kurnia Syabana, Yudi Satria, dan Robets Cristianto \\ Balai Besar Kerajinan dan Batik, Jl. Kusumanegara No. 7 Yogyakarta, Indonesia \\ irfasalma@gmail.com
}

Tgl Masuk Naskah: 04 September 2018

Tgl Masuk Revisi: 24 Oktober 2018

Tgl Disetujui: 25 Oktober 2018

\begin{abstract}
ABSTRAK
Indonesia memiliki kekayaan berbagai jenis kain tradisional indah dan unik, salah satunya adalah kain tenun ikat. Tenun ikat memiliki pola-pola tertentu yang menghasilkan motif-motif khas untuk keperluan tradisional. Seiring dinamika perkembangan zaman dan selera fesyen yang berubah, maka perlu dilakukan pengembangan desain motif baru sesuai dengan tuntutan zaman. Penelitian dan penciptaan seni ini bertujuan melakukan diversifikasi produk baru dengan cara mengombinasikan teknik tenun ikat dan teknik batik dalam selembar kain. Metode yang digunakan adalah pengumpulan data, perancangan desain tenun ikat kombinasi batik, pengikatan dan pencelupan warna, penenunan, dan pembatikan. Tematik motif yang diangkat yaitu seni budaya Nusa Tenggara Timur. Produk baru paduan tenun dan batik ini disingkat nuntik (tenun dan batik). Kegiatan ini menghasilkan tujuh motif nuntik yaitu Motif Jago, Motif Gading, Motif Gajah, Motif Kapas, Motif Lontar, Motif Tumpal, dan Motif Perhiasan.
\end{abstract}

Kata kunci: diversifikasi, desain, tenun ikat, batik, nuntik, Nusa Tenggara Timur

\begin{abstract}
Indonesia has a different types of beautifully decorated traditional fabrics admired by the world, one of which is fabrics produced by the technique of tie weaving. Traditional ikat motifs have certain patterns that produce distinctive motifs to meet various traditional activities or ceremonies. Along with the dynamics of times and changing fashion tastes, it is necessary to develop a new motif design in accordance with the demands of times. This art research and creation aims to improve aesthetic values or discover new aesthetics as a result of combining ikat weaving techniques and batik techniques in a piece of cloth. The methods used are data collection, design weaving bundle of batik combination, binding and dyeing, weaving, and batik. Thematic traditional motifs adopted are the arts of East Nusa Tenggara, because it is hoped that the technology and design of the motifs produced can be a diversification of new weaving products typical of East Nusa Tenggara. This new product of batik weaving / batik is shortened nuntik (tenun and batik). This research produced seven motive motions, namely Motif Jago, Motif Gading, Motif Gajah, Motif Kapas, Motif Lontar, Motif Tumpal, dan Motif Perhiasan.
\end{abstract}

Keywords: Value increase, design, batik alloy weaving, nuntic, East Nusa Tenggara

\section{PENDAHULUAN}

Tenun merupakan salah satu produk tekstil tradisional Indonesia yang masih lestari dan berkembang di masyarakat. Tenun ikat adalah seni membuat kain dengan cara menenun benang dan pembuatan motifnya dengan cara diikat dengan tali plastik menurut pola tertentu sebelum dicelupkan 
pada zat warna (Setiawan \& Suwarningdyah, 2014). Komposisi motif terwujud karena perbedaan warna benang, benang yang diikat tetap putih, sedangkan yang terbuka terwarnai oleh zat pewarna (Kartiwa, 2007). Sari (2014) juga menjelaskan bahwa tenun ikat adalah jenis tenun yang cara membuatnya dilakukan dengan mengikat bagian-bagian benang terlebih dahulu menurut pola/motif tertentu agar tidak terkena oleh warna celupan, sedangkan bagian-bagian yang tidak diikat berubah warna sesuai dengan warna yang dicelupnya, baru kemudian ditenun seperti biasa. Ada tiga jenis tenun ikat yaitu tenun ikat lungsi di mana bentuk ragam hias ikat pada kain tenunnya terdapat pada bagian beng lungsinya. Tenun ikat pakan di mana bentuk ragam hias ikat pada kain tenun terdapat pada bagian benang pakannya. Tenun berganda atau dobel ikat yaitu bentuk ragam hias pada kain tenun dihasilkan dengan cara mengikat baik pada bagian benang pakannya maupun benang lungsinya (Kartiwa, 2007). Salah satu daerah penghasil kain tenun yang terkenal adalah Nusa Tenggara Timur.

Nusa Tenggara Timur (NTT) dikenal memiliki banyak kerajinan tenun tradisional yang tumbuh dan berkembang secara turuntemurun dalam masyarakat, seperti tenun ikat Sumba, tenun ikat Kupang, kain Timor, tenun Buna, tenun Lotis, dan lain-lain. Motifmotif tradisional tenun ikat daerah Nusa Tenggara Timur mempunyai bentuk yang unik, indah, mengandung makna filosofis (Pudjiastuti, 2002). Motif tenun ikat tradisional mempunyai ciri khas motif dengan pola geometris, karena pada dasarnya teknis tenun adalah penganyaman benang lusi dan pakan (Salma, Eskak, \& Wibowo, 2016). Pola geometris adalah desain motif dengan pola yang terukur, berulang dengan teratur.
Tenun ikat memiliki ciri yang khas, bahkan setiap pulau menghasilkan corak dan ragam hias dengan keunikan masing-masing. Pulau Sumba memiliki tenun khas dengan motif hewan, Pulau Rote dengan motif khas daunnya dan Pulau Timor khas dengan tenun sutera dan bordir. Ciri khas tenun dari Alor adalah tenun ikat lusi dan pewarnaannya masih menggunakan pewarnaan alam baik dari tumbuh-tumbuhan dan biota laut seperi cumi, teripang dan rumput laut (Farida, Salma, Satria, Syabana, Christianto, Lestari, Sudiarti, \& Hardjanto, 2017).

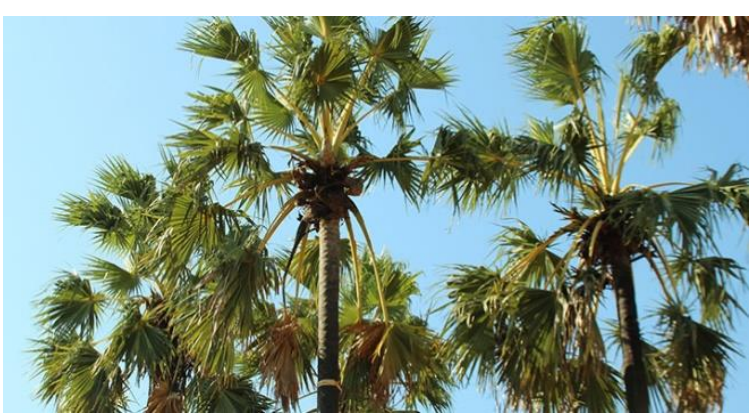

Gambar 1. Pohon lontar yang banyak tumbuh di Nusa TenggaraTimur

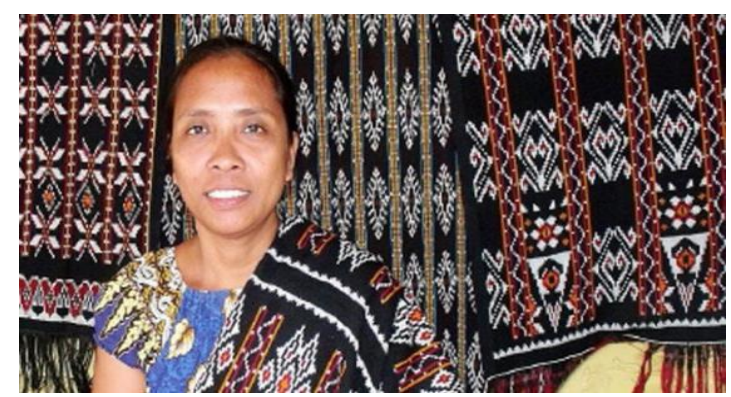

Gambar 2. Kain tenun ikat tradisional NTT dari Rote Ndao, karya Fransina (67 tahun)

Kekayaan alam antara lain berupa pohon-pohon khas daerah (Gambar 1) dan aneka ragam hias motif tenun ikat tradisional Kupang (Gambar 2) merupakan kekayaan budaya yang berharga. Kekayaaan ragam hias tradisional dalam era industri kreatif dewasa ini dapat dijadikan sumber inspirasi penciptaan seni kreatif dan inovatif sesuai dinamika zaman (Yoga \& Eskak, 2015). 
Keunikan alam dan ragam hias seperti inilah yang akan digali dan dikembangkan untuk penciptaan motif batik baru yang mempunyai kekhasan daerah. Banyak pengembangan industri batik di daerah yang kurang mengakomodir potensi seni budaya lokal, sehingga motif-motif baru yang dihasilkan kurang bahkan tidak memiliki ciri khas kedaerahan (Salma, 2014).

Dewasa ini pemasaran kain tenun ikat NTT mengalami kelesuan. Fransina (67 tahun) perajin tenun ikat dari Dusun Ndao, Kecamatan Lobalain, menuturkan bahwa produk tenun yang dihasilkan secara turuntemurun membuat kain dengan cara tradisional saja, tidak berubah sejak dari dahulu (Ama, 2013). Hasil analisis menunjukkan bahwa salah satu penyebab lesunya pasar adalah karena produk yang dihasilkan relatif monoton atau kurang beragam baik. Permasalahan kurangnya diversifikasi produk tenun ikat tersebut akan dicarikan solusinya dalam penelitian ini, yaitu penelitian penciptaan seni untuk menciptakan desain motif tenun baru yang dihasilkan dari kombinasi teknik tenun ikat dengan teknik batik, yang inspirasi penciptaan motifnya diambil dari alam dan budaya khas daerah Nusa Tenggara Barat.

Berkaitan dengan permasalahan tersebut maka perlu juga dilakukan kajian tentang teknik batik menurut beberapa pakar di bidangnya. Batik sebagai karya seni dekoratif pada kain mempunyai beberapa keunggulan untuk dikembangkan di berbagai daerah yang belum mempunyai tradisi membatik (Salma, Eskak, \& Wibowo, 2016). Teknik batik relatif mudah diterapkan di berbagai daerah karena umumnya masyarakat Indonesia mempunyai kepandaian tinggi dalam bidang seni (Eskak, 2016). Batik merupakan teknik membuat motif hias pada kain dengan menggunakan malam (lilin batik) dan canting. Canting berguna untuk menorehkan malam panas pada kain. Canting tradisional ada dua yaitu canting tulis atau canting cap (Eskak, 2013). Bidang kain yang ditorehi malam akan tidak teresapi warna, sedangkan bagian kain yang terbuka akan terwarnai.

Tujuan penelitian ini adalah untuk menciptakan desain motif tenun baru yang dihasilkan dari kombinasi teknik tenun ikat dengan teknik batik, yang inspirasi penciptaannya diambil dari alam dan budaya khas daerah setempat.

\section{METODOLOGI PENELITIAN}

Metode yang digunakan yaitu pengumpulan data, pengkajian sumber inspirasi, pembuatan desain motif, pengikatan benang sesuai desain motif, pewarnaan alam, proses penenunan, dan proses pembatikan, dan evaluasi produk jadi.

\section{Bahan dan Alat}

Bahan dan alat yang digunakan dipilah menjadi dua bagian yaitu bahan dan alat untuk membuat desain nuntik di atas kertas dan untuk membuat produk purwarupa nuntik. Bahan dan alat pembuatan desain secara manual adalah kertas gambar, kertas padalarang, kertas manila, kertas milimeter block, kertas pola, pensil 2B, pensil warna, karet penghapus, spidol hitam kecil, tinta hitam, cat warna, penggaris, kuas, palet, dan meja kaca. Bahan dan alat untuk pembuatan desain dengan komputer adalah set PC grafis, printer, dan flashdisk.

Bahan dan alat untuk pembuatan tenun nya adalah benang katun, warna alam, tali rafia, alat colet, kuas, bak celup, bak ekstraksi, bak mordanting, plangkan, pengurai benang, dan ATBM. Sedangkan bahan dan alat pembatikannya adalah adalah canting tulis, canting cap, kompor batik, timbangan warna, bak pewarnaan, malam batik, alat colet, kuas, bahan warna alam, 
bahan pembantu pewarnaan, air tawar bersih, kompor loro, peralatan pelorodan, penjemuran teduh, dan setrika.

\section{Prosedur Kerja}

Pengumpulan data dilakukan dari dua sumber, yaitu data primer dan data sekunder. Data primer tentang seni budaya daerah Nusa Tenggara Timur didapatkan dari observasi langsung ke daerah tersebut. Dilengkapi pula data dari literatur yang relevan sebagai data sekunder. Data tersebut kemudian dikaji secara mendalam untuk memperoleh inspirasi penciptaan motif tenun kombinasi batik. Mekanisme untuk mendapatkan inspirasi penciptaan dilakukan dengan melihat bentuk objek dengan usaha pemahaman mendalam tentang objek tersebut, selanjutnya menggali bentukbentuk motif yang ingin dibuat. Ide yang ada dalam pikiran kemudian dipindahkan dalam bentuk nyata dengan pembuatan sketsasketsa di atas kertas. Dari sketsa-sketsa yang dihasilkan, selanjutnya dipilih yang terbaik untuk diproses menjadi desain motif tenun kombinasi batik. Desain dibuat terukur menjadi pola motif, dengan menyiapkan bidang-bidang disela-sela atau di dalam motif dibuat polos yang nantinya akan diberi batikan. Pola motif yang sudah jadi kemudian dipindahkan ke benang dengan cara diikat membentuk motif sebelum dicoled ataupun dicelup warna. Warna yang digunakan adalah warna alam.

Proses selanjutnya adalah proses menenun untuk membuat menjadi lembaran kain. Kain tenunan yang sudah jadi, kemudian dilakukan proses penambahan dekorasi lagi dengan teknik batik. Proses batik yang dilakukan sama seperti pada proses batik pada umumnya yaitu pelekatan lilin batik, pewarnaan, dan pelorodan. Untuk mendapatkan variasi warna, dilakukan juga variasi proses, terutama pengulangan pelekatan lilin dan pewarnaannya. Pewarnaan batik dilakukan dengan variasi colet dan celup. Pewarnaan batik dalam kegiatan ini menggunakan pewarna alam, sebagaimana para penenun tradisional NTT mewarnai produk mereka dengan menggunakan pewarna dari bahan alami yang didapat dari lingkungan sekitar mereka. Setelah pembuatan propotipe produk batik selesai, kemudian dilakukan evaluasi terhadap produk yang dihasilkan. Secara ringkas proses pembuatan nuntik motif khas Nusa Tenggara Timur dapat dilihat dalam Gambar 3.

\section{HASIL DAN PEMBAHASAN Hasil}

Kegiatan ini menghasilkan purwarupa kain tenun kombinasi batik, dengan pewarnaan alam. Untuk mempermudah penyebutan, maka akan dipakai akronim "nuntik", tenun dan batik menjadi nuntik. Kata "nuntik" kemudian akan dipakai pada kalimat-kalimat berikutnya untuk menyebut pengertian kain yang dihasilkan dari perpaduan antara teknik tenun yang dikombinasi dengan teknik batik.

Teknologi proses maupun desain produk nuntik ini sebagai upaya diversifikasi untuk dapat meningkatkan daya saing produk fesyen Indonesia. Desain purwarupa yang dihasilakn dari kegiatan ini adalah: (1) Motif Jago; (2) Motif Gading; (3) Motif Gajah; (4) Motif Kapas; (5) Motif Lontar; (6) Motif Tumpal; dan (7) Motif Perhiasan. 


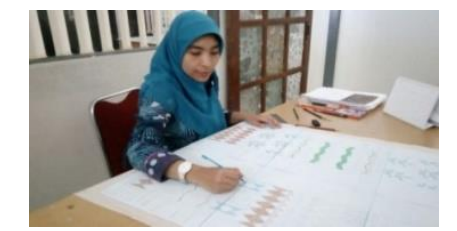

Mendesain motif

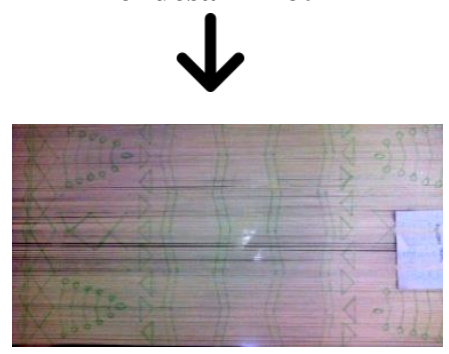

Pemindahan motif ke benang di alat plangkan

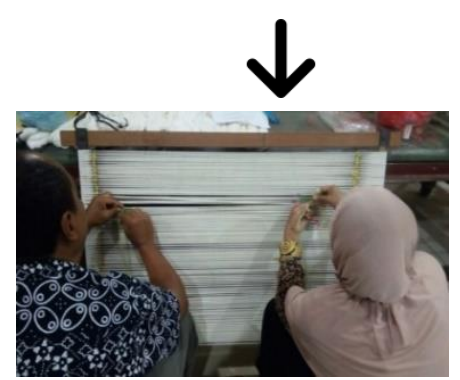

Mengikat benang sesuai motif

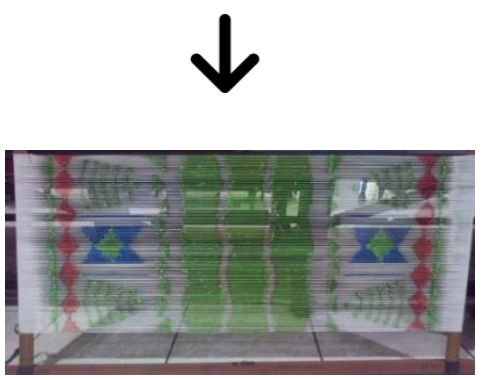

Hasil ikatan siap dicelup warna

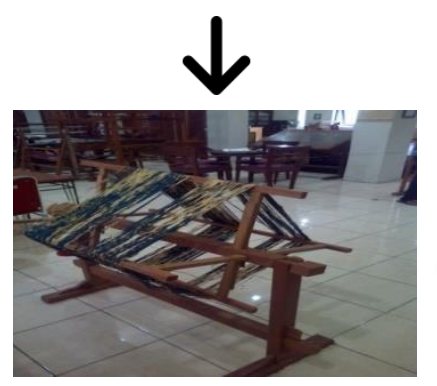

Benang yang sudah diwarna dan sudah dibuka ikatannya, siap dipindah ke ATBM

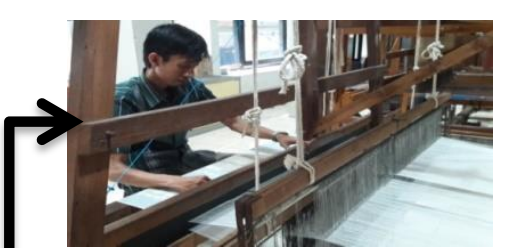

Proses Penenunan

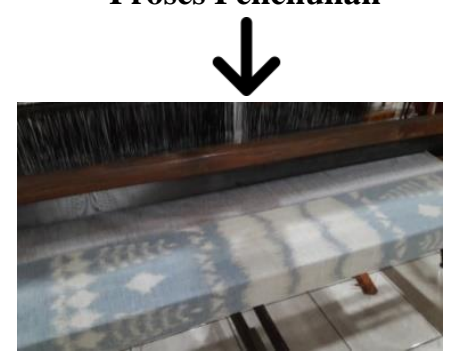

Hasil tenunan, motif yang polos longgar tersebut akan diberi batikan
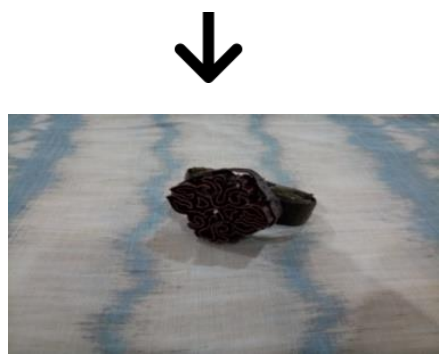

Proses batik dengan teknik batik cap

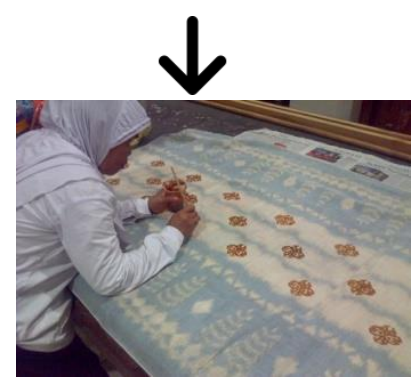

Pewarnaan batik dengan teknik colet

Gambar 3. Alur pembuatan motif tenun kombinasi batik 


\section{Pembahasan}

Kegiatan ini dilaksanakan dengan beberapa tahapan yaitu; identifikasi desain motif melalui kunjungan ke daerah yang akan diciptakan motif-motif dalam kegiatan ini yaitu Nusa Tenggara Timur dan Jepara. Kunjungan lapangan terkait dengan eksplorasi ragam seni budaya dan kekayaan sumber daya alam khas daerah tersebut. Hasil dari identifikasi ragam hias khas daerah tersebut, kemudian dianalisis sebagai asupan ide rancangan yang akan dituangkan kedalam bentuk sketsa gambar desain motif tenun kombinasi batik, kemudian dilakukan pemindahan desain motif pada plangkan untuk selanjutnya dilakukan pengikatan benang sesuai desain motif yang dibuat. Rancangan motif dibuat dalam beberapa alternatif, untuk dipilih yang terbaik untuk dikerjakan menjadi produk nuntik. Rancangan tersebut antara lain dapat dilihat dalam Gambar 4 yaitu motif Lontar, dan Gambar 5 yaitu motif Jago.

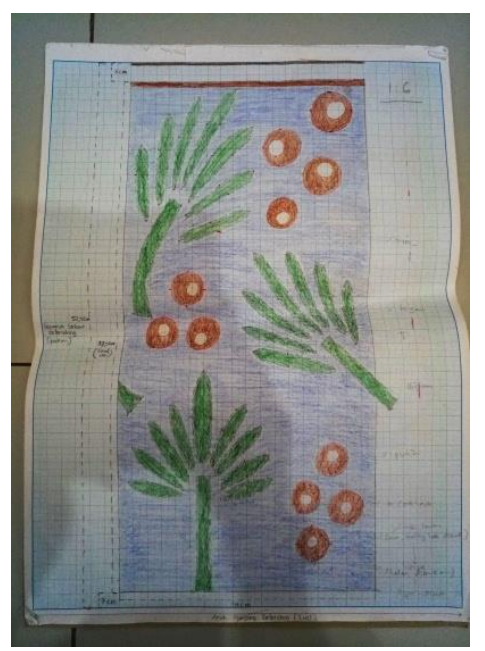

Gambar 4. Desain motif Lontar dan hasil pengikatan pada plangkan

Pembuatan dan pemilihan beberapa desain motif pengembangan atas dasar unsur sejarah, nilai budaya dan adat daerah, seperti motif Jago atau ayam jantan diambil dari dunia fauna yang melambangkan kekuasaan,

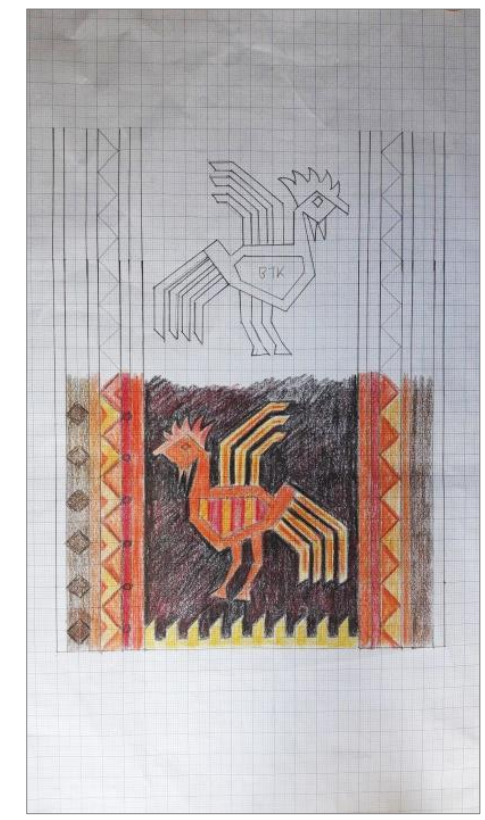

Gambar 5. Desain motif Jago

kekuatan dan keperkasaan. Motif Gajah merupakan adanya hubungan dengan dunia luar seperti India dan Belanda, yang diperkuat adanya temuan fosil rahang gajah di Watumbaka - Wangaipu di Sumba (Hebi, 2014). Sedangkan motif Kapas diambil karena sejatinya IKM tenun di NTT telah menanam kapas dipekarangan rumah mereka dan memintal sendiri serat kapas sebagai bahan baku untuk membuat benang, sebelum adanya benang hasil pintalan pabrik. Motif lontar dipilih karena untuk membuat kain tenun ikat, ikm tenun NTT menggunakan daun lontar sebagai media perintang warna dan pembentuk motif.

Dalam menggabungkan desain motif tenun kombinasi batik perlu dipikirkan keharmonisan bentuk, ukuran, warna. Karena keduanya memiliki karakteristik yang unik yang tidak dimiliki satu dengan yang lainnya. Untuk itu dalam membuat rancangan desain, teknik tenun lebih terbatas dalam hal keluwesan motif, tidak dapat membuat desain yang detail dan rumit. Ciri khas dari tenun ikat yaitu adanya pergeseran motif akibat perbedaan tegangan benang dan 
silangan antara benang lusi dan benang pakan.

Produk tenun kombinasi batik dibuat untuk selendang dan bahan sandang/ sarung, karena lebih banyak dipakai untuk pakaian sehari-hari. Penggunaan benang katun dengan nomer Ne1 64/2, Ne1 40/2 lebih bagus untuk hasil pegangan, daya langsai sehingga dapat dengan nyaman dipakai. Karena selama ini kain tenun ikat dari IKM NTT cenderung lebih kasar pegangannya dan tebal karena benang yang dipakai besar dan dirangkap 2 - 3 helai untuk benang pakannya. Hal ini karena masih banyak dikerjakan dengan alat tenun gedogan, yang memiliki kapasitas produksi rendah. Selembar kain tenun ikat dihasilkan dari 1 kali proses menenun, berbeda jika menenun dengan alat tenun bukan mesin (ATBM) yang dapat menghasilkan produk lebih banyak.

Hasil produksi tenun ikat lebih lama dibandingkan dengan produksi tenun tradisional lainnya seperti tenun lurik, karena urutan proses persiapannya lebih panjang. Kendala yang dihadapi pada persiapan awal benang seperti putus benang pada saat menggulung ke plangkan jika tidak disambung maka akan terus terbawa sampai ke proses selanjutnya.

Hasil mordan awal antara jirak dan tawas berbeda, untuk mordan jirak karena berasal dari daun dan memiliki pigmen warna sehingga mewarnai bahan cenderung kearah kuning. Akan tetapi untuk ketahanan lunturnya masih kurang baik, karena kandungan unsur $\mathrm{Al}$ pada jirak lebih sedikit yaitu 49.775 ppm dibandingkan tawas 59.892.

Bahan warna yang digunakan adalah pewarna dari alam. Pada pembuatan produk nuntik diperlukan teknik pewarnaan yang tepat untuk mempertahankan kualitas warnanya. Pewarnaan alam pada tenun dilakukan dengan mewarnai benang yang akan digunakan dan dapat dilakukan pada suhu tinggi maupun perendaman pada suhu rendah, sedangkan pewarnaan alam pada proses batik harus melalui proses pelorodan menggunakan air panas pada suhu tinggi dapat mempercepat proses penyerapan warna, tetapi berakibat masuknya sebagian warna (merembes) ke dalam ikatan. Pada penelitian ini, digunakan beberapa macam zat warna alam, diantaranya serutan kayu secang dan akar mengkudu untuk warna alam merah, indigofera untuk warna alam biru,. kunyit dan tegeran untuk warna alam kuning, serta warna alam coklat soga meliputi jalawe, tingi, dan jambal.

Pada waktu mencelup benang, kendala yang ditemui yaitu benang mudah kusut karena berkaitan satu dengan yang lain terkena ujung dari simpul ikatan. Terlebih pada gulungan benang tanpa ikatan, cenderung lebih mudah kusut karena tidak ada ikatan. Pencelupan dilakukan dengan suhu kamar hal ini disebabkan apabila dilakukan dengan panas maka hasil warna akan lebih cepat meresap ke benang akan tetapi beresiko akan rembesan warna pada ujung ikatan. Terutama apabila hasil ikatan kurang kuat, padat dan bahan tali raffia tipis mudah sobek maka warna akan mudah masuk dan merembes akibatnya motif yang terbentuk tampak kurang bagus.

Proses pewarnaan pada tenun berkebalikan dengan pewarnaan pada batik, yaitu dari mulai warna yang paling gelap ke medium dan muda. Pencelupannya dilakukan secara bertahap, untuk mewarna yang lebih muda dilakukan dengan cara membuka ikatan terlebih dahulu baru kemudian dicelup. Pada batik, pewarnaan dilakukan dengan warna muda terlebih dahulu kemudian ditutup sebagian motif dengan malam untuk mempertahankan warna muda yang telah didapatkan untuk kemudian dicelup warna selanjutnya yang 
lebih tua. Pencelupan warna alam yang berulang juga menyebabkan kekuatan benang berkurang, akibat puntiran yang terbuka. Pembukaan ikatan untuk tiap warna yang berbeda harus teliti, karena dapat menyebabkan kesalahan motif jika keliru melepas ikatan tali raffia. Disamping itu juga saat membuka ikatan harus hati-hati agar benang tidak ikut putus terkena pisau /cutter. Ketika benang putus perlu disambung, jika tidak akan menyebabkan kesulitan pada waktu pembongkaran benang seperti benang melintir dan kusut.

Waktu pencelupan yang dilakukan selama 30 menit karena proses pencelupan yang dipakai celupan dingin sehingga warna dapat masuk dan berikatan dengan benang membutuhkan waktu secara bertahap. Dan pencelupan dilakukan secara berulang sampai dihasilkan warna yang diinginkan. Pencelupan dengan jalawe dengan fiksasi baik tunjung, tawas pada pewarnaan pertama cenderung menyebabkan melunturi hasil ikatan sehingga tidak cocok untuk pencelupan warna pertama. Selain itu hasil pencelupan dengan jalawe pada pewarnaan kedua atau terakhir menyebabkan hasil warna awal dan kedua berubah kalah oleh warna jalawe. Teknik pewarnaan untuk tenun dipakai teknik celup, sedangkan teknik pewarnaan batik dipakai teknik colet atau kuas. Hal ini dimaksudkan agar warna pada tenun ikat tidak ikut berubah ketika pewarnaan batik.

Terdapat perbedaan antara tenun ikat lusi dan ikat pakan terutama pada waktu menggulung ke plangkan, untuk ikat pakan jumlah helai yang digulung menyambung terus sampai jumlah gulungan sesuai rencana. Berbeda dengan ikat lusi, jumlah helai benang dihitung berdasarkan lebar kain dan nomer sisir tenun yang akan dipakai serta gulungannya tidak menyambung. Pada tenun ikat lusi, motif yang terbentuk akibat ikatan pada benang lusi. Sedangkan pada ikat pakan, motif terbentuk akibat ikatan pada benang pakan. Pergeseran motif pada tenun ikat dikarenakan adanya perbedaan tegangan benang dan silangan antara benang lusi dan benang pakan. Pada ikat lusi relatif sedikit pergeseran benangnya, karena benang diatur sedemikian rupa sehingga motif terbentuk dengan baik sebelum digulung pada boom lusi. Pembentukkan motif pada ikat pakan diatur pada saat menenun, akibat tarikan benang pakan yang bergerak ke kanan - ke kiri dan terjadi silangan antara benang lusi dan benang pakan maka pergeserannya lebih banyak.

\section{Aspek Pasar dan Kelayakan Ekonomi}

Pasar produk nuntik warna alam mempunyai prospek yang baik, seiring meningkatnya kesadaran masyarakat terhadap efek negatif warna sintetis terhadap kesehatan dan lingkungan. Sebagai produk baru, nuntik mempunyai keunggulan yaitu: (1) Memiliki desain motif yang unik karena merupakan hasil gabungan teknik tenun ikat dan batik. (2) Memiliki warna yang unik karena menggunakan pewarna alam. (3) Desain motif yang lebih beragam.

Pola produksi industri tradisional, biasanya terjebak pada pengulangan desain tradisi yang cenderung monoton sehingga produk yang dihasilkan kurang beragam. Oleh karena itu diperlukan diversifikasi produk dengan menampilkan desain motif baru, sehingga konsumen kembali tertarik membeli motif baru, karena sesuatu kebaruan itu senantiasa memiliki daya tarik (Sukaya, Eskak, dan Salma, 2017).

Penggunaan zat warna alam sebagai pewarna nuntik akan dapat mengurangi penggunaan zat warna sintetis, sehingga 


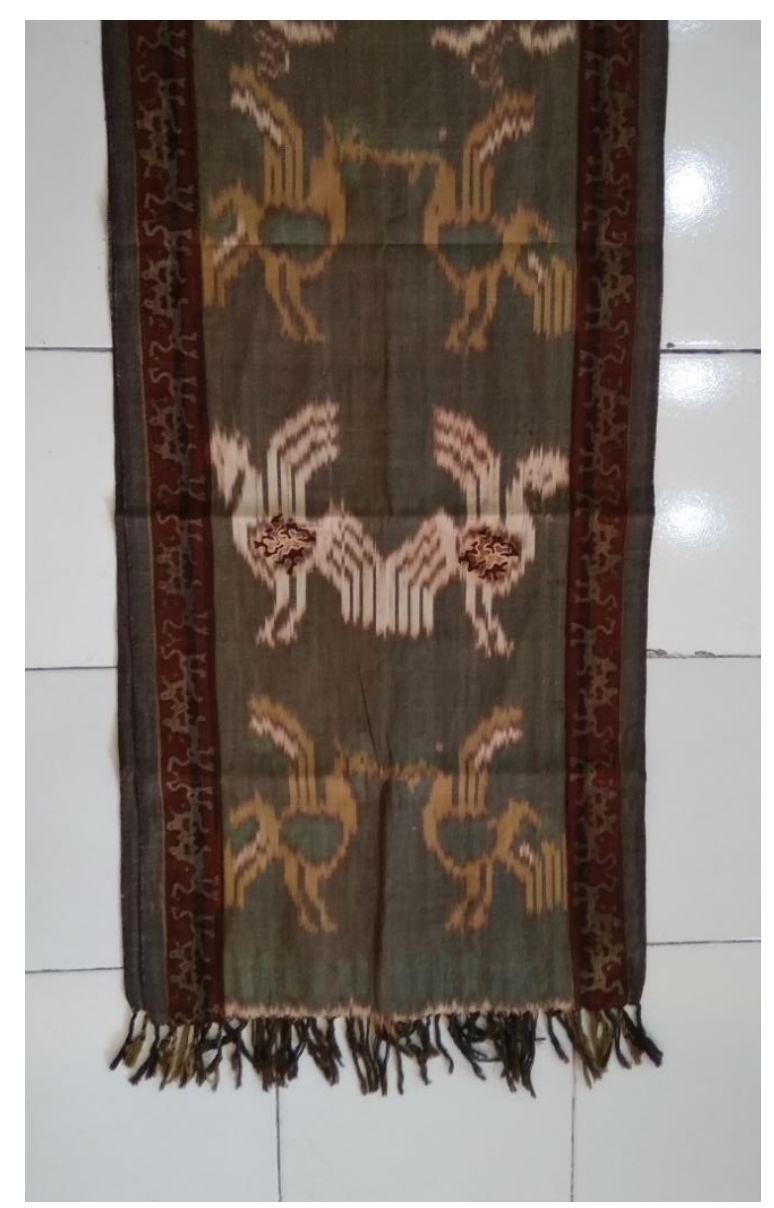

Gambar 6. Nuntik motif Jago

dengan warna alam (Foto: Edi Eskak, 2018)

dapat menurunkan ketergantungan terhadap bahan baku impor. Produk nuntik warna alam memiliki potensi pasar yang prospektif karena merupakan produk inovatif yang dikreasikan selaras dengan semangat melestarikan seni budaya lokal dan industri kreatif yang ramah lingkungan.

\section{Aspek Kelayakan Sosial dan Lingkungan}

Membuka potensi IKM Tenun dan Batik untuk memproduksi produk inovatif yaitu nuntik. Kerajinan tenun mempunyai potensi untuk dapat menampung banyak tenaga kerja, menopang perekonomian masyarakat, dan pada gilirannya dapat meningkatkan kesejahteraan masyarakat (Setiawan \& Suwarningdyah, 2014). Semakin berkembangnya IKM tenun dan batik akan dapat menyerap tenaga kerja lebih banyak dan mengurangi tingkat pengangguran, dengan demikian inovasi ini mempunyai nilai kelayakan sosial yang tinggi.

Penggunaan warna alam dengan memanfaatkan potensi sumber daya alam lokal disekitarnya, turut mengurangi pencemaran lingkungan akibat penggunaan zat warna kimia/sintetis. Produk inovatif nuntik ini merupakan produk yang ramah lingkungan/green product.

\section{KESIMPULAN DAN SARAN \\ Kesimpulan}

Diversifikasi produk tenun dengan mengombinasikan teknik tenun ikat dan teknik batik dalam penelitian ini telah menghasilkan produk baru yang kemudian diberi nama "nuntik", sebuah akronim dari penggabungan akhir kata "tenun dan batik". Penggunaan warna alam semakin menambah keunikan dan keeksotisan produk yang dihasilkan. Hasil analisis Aspek Pasar dan Kelayakan Ekonomi menunjukkan bahwa produk yang dihasilkan mempunyai potensi pasar sebagai produk seni ramah lingkungan yang disukai konsumen menengah atas. Sedangkan hasil analisis dari Aspek Kelayakan Sosial dan Lingkungan menunjukkan bahwa inovasi desain produk nuntik turut memperlancar dan memajukan IKM, yang akan berdampak positif pada lingkungan sosial dan lingkungan alam.

\section{Saran}

Perlu banyak melakukan percobaan dan penelitian lebih lanjut dalam pembuatan nuntik dengan perwarna alami ini, agar didapatkan hasil yang optimal dalam segi bahan baku, proses perencanaan tenun, pemilihan desain, teknik pewarnaan, penggunaan bahan pewarna dan fiksasi sehingga dihasilkan kain nuntik warna alam yang berkualitas. 


\section{UCAPAN TERIMA KASIH}

Terselesaikannya penelitian ini tidak lepas dari bantuan berbagai pihak, oleh karena itu disampaikan terima kasih kepada: Kepala Balai Besar Kerajinan dan Batik (BBKB), Kabid Saristand BBKB, Pengelola DIPA BBKB 2017, IKM tenun ikat Troso Jepara, IKM tenun ikat Nusa Tenggara Timur, Disperindag Nusa Tenggara Timur, Edi Eskak M.Sn atas ide penamaan "nuntik" sebagai akronim (tenun + batik = nuntik), serta pihak-pihak yang telah banyak membantu dalam penelitian dan penciptaan seni ini.

\section{DAFTAR PUSTAKA}

Ama, K. K. (2013). Tenun Ikat Memuliakan Perempuan. diakses dari https://travel.kompas.com/read/2013/07/20/ 1803184/Tenun.Ikat.MemuliakanPerempua n, pada tanggal 14 Juli 2018.

Eskak, E. (2013). Mendorong Kreativitas dan Cinta Batik Pada Generasi Muda. Dinamika Kerajinan dan Batik, 30(1), 1-10.

Eskak, E. (2016). Bambu Ater (Gigantochloa Atter) Sebagai Bahan Substitusi Kayu Pada Ukiran Asmat. Dinamika Kerajinan dan Batik, 33(1), 55-66.

Farida, Salma, I. R., Satria, Y., Syabana, D. K., Christianto, R., Lestari, D. W., Sudiarti, E., dan Hardjanto, P. (2017). Pengembangan Desain Motif Tenun Kombinasi Batik Dengan Pewarna
Alami. Laporan Penelitian. Balai Besar Kerajinan dan Batik, Yogyakarta.

Kartiwa, S. (2007). Tenun Ikat. Jakarta: Gramedia Pustaka Utama.

Hebi, F. (2014). Motif dan Makna Pada Kain Ikat Sumba Timur. Waingapu. Retrieved from http://maxfmwaingapu.com/2014/11/semiot ik-motif-dan-makna-pada-kain-ikat-sumbatimur/

Pudiastuti, W. 2002. Buku Motif Tenun Ikat Sumbawa. Yogyakarta: Institut Seni Indonesia.

Salma, I. R. (2014).Seni Ukir Tradisional Sebagai Sumber Inspirasi Penciptaan Batik Khas Baturaja. Dinamika Kerajinan dan Batik. 31(2), 75-84.

Salma, I. R., Eskak, E., dan Wibowo, A. A. (2016). Kreasi Batik Kupang. Dinamika Kerajinan dan Batik,. 33(1). 45-54.

Sari, N. M. (2014). Tenun Ikat Atbm Di Home Industry Kurniawan Bandar Kidul Kediri Jawa Timu. Skripsi. Fakultas Bahasa dan Seni. Universitas Negeri Yogyakarta.

Setiawan, B., dan Suwarningdyah, N.R.R. (2014). Strategi Pengembangan Tenun Ikat Kupang Propinsi Nusa Tenggara Timur. Jurnal Pendidikan dan Kebudayaan, 20(3), 353-367.

Sukaya, Y., Eskak, E., dan Salma, I. R. (2017). Penambahan Nilai Guna Pada Kreasi Baru Produk Boneka Batik Kayu Krebet Bantul. Dinamika Kerajinan dan Batik. 35(1). 4554.

Yoga, W. B. S., dan Eskak, E. (2015). Ukiran Bali Dalam Kreasi Gitar Elektrik. Dinamika Kerajinan Dan Batik, 32(2), 117-126. 